\title{
Jean-Martin Charcot (1825-1893) and his second thoughts about hysteria
}

\author{
Jean-Martin Charcot (1825-1893) y sus dudas sobre la histeria
}

Francesco BRIGO'

\begin{abstract}
Jean-Martin Charcot's (1825-1893) concepts of hysteria evolved significantly over the last 20 years of his career. In the "Leçons du Mardi à la Salpêtrière" (Tuesday lessons), his original conception of a "dynamic lesion" coexists alongside a new psychological conception, sometimes in a rather contradictory way. According to the hand-written transcript of his Tuesday lesson on February $21^{\text {st }}$, 1888, Charcot stated: "Hysteria must be taken for what it is: psychic disease par excellence". However, in the printed edition of the Tuesday lessons, this emphasis on psychological factors was very much softened. The different wording and corresponding shift in meaning implicitly retrieved Charcot's former conception of a "dynamic lesion". Charcot himself had probably been made aware of the different wording by the editors, and had agreed upon it. After several years of studying this condition, Charcot was probably not confident enough in making too assertive conclusions on the psychological mechanisms underlying hysteria.
\end{abstract}

Keywords: History of Medicine; Hysteria; Salpêtrière.

\section{RESUMEN}

Los conceptos de Jean-Martin Charcot (1825-1893) sobre la histeria evolucionaron significativamente durante los últimos 20 años de su carrera. En las "Leçons du Mardi à la Salpêtrière", su concepción original de una "lesión dinámica" coexiste junto con una nueva concepción psicológica, a veces de una manera bastante contradictoria. Según la transcripción manual de su lección del martes del 21 de febrero de 1888, Charcot declaró: "La histeria debe tomarse por lo que es: enfermedad psíquica por excelencia”. Sin embargo, en la edición impresa de las lecciones del martes, este énfasis en los factores psicológicos se suavizó mucho. La diferente redacción y el cambio correspondiente en el significado recuperaron implícitamente la antigua concepción de Charcot de una “lesión dinámica". El proprio Charcot probablemente se había enterado de la diferente redacción por parte de los editores y lo había aceptado. Después de varios años estudiando esta afección, Charcot probablemente no estaba lo suficientemente seguro para sacar conclusiones demasiado asertivas sobre los mecanismos psicológicos subyacentes a la histeria.

Palabras clave: Historia de la Medicina; Histeria; Salpêtrière.

Jean-Martin Charcot (1825-1893) is widely considered the father of modern Neurology. While working as Chief of Service at La Salpêtrière (1862-1893), he became increasingly interested in hysteria. His concepts on this enigmatic condition have evolved significantly over the last 20 years of his career, which explains why they can sometimes appear contradictory ${ }^{1}$. Charcot had initially regarded hysteria as an organic disease, seeking a cerebral localization through autopsy and anatomopathological exam. His failure led him to consider hysteria as the consequence of a "dynamic lesion" ("lésion fonctionnelle" or "lésion dynamique") of the nervous system; such explanation accounted for the lack of detectable morphological lesions in the brain of hysterical patients ${ }^{2}$. Furthermore, he vehemently rejected the equation between hysteria and simulation. Charcot became increasingly convinced of the importance of psychological factors in the genesis of hysteria only shortly before his death ${ }^{3}$; this idea would have been further developed by his pupil Pierre Janet (1859-1947). In Charcot's latest works, the original conception of a "dynamic lesion" coexists alongside the new psychological conception, sometimes in a rather contradictory way.

The "Leçons du Mardi à la Salpêtrière" (Tuesday lessons) are transcriptions of impromptu clinical presentations held by Charcot between 1887 and 1889. They incorporate the dialogues between Charcot and his patients, reflecting the spontaneity of real-life interactions ${ }^{4}$. Hand transcriptions of the lessons were made by his students, Edouard-Emmery Blin (1863-1930), Jean-Baptiste Charcot (1867-1936), and Henri

${ }^{1}$ Department of Neurology, Hospital of Merano (SABES-ASDAA), Merano-Meran, Italy.

Francesco BRIGO (iD https://orcid.org/0000-0003-0928-1577

Correspondence: Francesco Brigo; E-mail: dr.francescobrigo@gmail.com

Conflict of interest: There is no conflict of interest to declare.

Received on April 23, 2020; Accepted on July 22, 2020. 
Colin (1860-1930); they underwent thorough editing and revision before print publication between 1889 and $1892^{5,6}$.

References to a "dynamic lesion" - a term still deeply rooted in an organic view of hysteria - recur frequently in the Tuesday lessons (see for instance lessons of January $17^{\text {th }}$, April $10^{\text {th }}$ and $17^{\text {th }}$, November $6^{\text {th }}$, December $4^{\text {th }}$ and $18^{\text {th }}, 1888$; and March $\left.5^{\text {th }}, 1889\right)^{5,6}$. In his Tuesday lesson on February $21^{\text {st }}, 1888$, Jean-Martin Charcot described a 14-year-old boy with chest pain, dyspnea, and the beginning of opisthotonos. According to the typescript, on this occasion - after having emphasized that hysteria was totally distinct from simulation in children - Charcot stated: "Hysteria must be taken for what it is: a psychic disease par excellence" ("Il faut prendre cette affection pour ce quelle est, c'est à dire pour une maladie psychique par excellence") (manuscript, page $205)^{7}$. Such statement has been widely quoted in the literature $^{8,9,10,11,12,13,14}$ as the most concise and vivid expression of Charcot's late psychic conception of hysteria.
Intriguingly, this statement was reported differently in the printed edition, where it reads as: "It is definitely the case to present hysteria as a disease which for three quarters is psychic" ("C'est le cas, ou jamais, de vous présenter l'hystérie comme une maladie aux trois quarts psychique") (page 138) ${ }^{6}$. Compared to the original handmade transcription, the statement sounds awkward and is definitely ambiguous: how else to consider the remaining quarter of non-psychic cases of hysteria? By weakening the emphasis on the psychological nature of hysteria, the different wording implicitly retrieves Charcot's former conception of a "dynamic lesion". The shift in meaning underlying the different wording is extremely relevant and, probably, Charcot himself had been made aware of this by the editors, and had agreed upon it. After over 20 years spent studying this condition, Charcot was probably not confident enough in making too assertive conclusions on the psychological mechanisms underlying hysteria.

\section{References}

1. Bogousslavsky J. Jean-Martin Charcot and his legacy. Front Neurol Neurosci. 2014 Jun;35:44-55. https://doi. org/10.1159/000359991

2. Goetz CG, Bonduelle M, Gelfand T. Charcot, constructing neurology. New York: Oxford University Press; 1995.

3. Bogousslavsky J, Moulin T. From alienism to the birth of modern psychiatry: a neurological story? Eur Neurol. 2009 Aug;62(5):257-63. https://doi.org/10.1159/000235594

4. Walusinski O. Georges Gilles de la Tourett: beyond the eponym. New York: Oxford University Press; 2019

5. Charcot JM. Leçons du Mardi à la Salpêtrière (1887-1889). Notes de Cours de MM. Blin, Charcot et Colin. Paris: Bureau du Progrès Médical; 1889.

6. Charcot JM. Leçons du Mardi à la Salpêtrière (1887-1889). Notes de Cours de MM. Blin, Charcot et Colin. Paris: Bureau du Progrès Médical; 1892.
7. Charcot JM. Leçons du Mardi à la Salpêtrière (1887-1888). Notes de Cours de MM. Blin, Charcot et Colin. Paris: Bureau du Progrès Médical; 1887.

8. Shorter E. From paralysis to fatigue: a history of psychosomatic illness in the modern era. New York: The Free Press; 1992.

9. Lepastier S. Un passé agité. Délire de mémoire hystérique et psychanalyse. Rev Fr Psychanal. 2001 Jan;65(3):873-92. https://doi. org/10.3917/rfp.653.0873

10. Postel J, Quétel C. Nouvelle histoire de la psychiatrie. Paris: Dunod; 2012.

11. Bouchara C. Charcot. Une vie avec l'image. Paris: Philippe Rey; 2013.

12. Barbas S. Gloire et déclin de l'hystérie infantile au xixe siècle. Chronique illustrée. Inf Psychiatr. 2014;90(1):65-77. https://doi. org/10.3917/inpsy.9001.0065

13. Cyrulnik B, Lemoine P. Histoire de la folie avant la psychiatrie. Paris: Odile Jacob; 2018.

14. Pirlot G, Cupa D. Approche psychanalytique des troubles psychiques. Paris: Dunod; 2019. 